\title{
If GERMANY CAME TO NEW ZEALAND
}

\author{
Professor John Salmond*
}

\section{PROFESSOR SALMOND'S INAUGURATION}

\section{AN INTERESTING ADDRESS}

Professor J W Salmond, recently appointed to the chair of law at Victoria College, last evening delivered his inaugural address at the college. There was a fair gathering of students and the public. The Mayor (Hon T W Hislop) was unable at the last moment to be present to preside. Professor von Zedlitz, chairman of the Professorial Board, introduced Professor Salmond, who was very cordially received.

\section{LAW, CIVIL AND INTERNATIONAL}

Professor Salmond dealt with the subject of "International law with regard to the conditions of modern warfare". It was by virtue of civil law, he said, that men lived together as peaceful members of one commonwealth. It was the function of international law to maintain peace and justice in the society of nations. Civil law declared the rights and duties of individual persons; the law of nations declared the rights and duties of sovereign states, and sought to substitute the rules of righteousness and justice for the unrestrained exercise of force in international relations. There was no Parliament having authority to establish the law of nations; and there was no mode of enforcement. International law was simply the rules agreed upon by civilised states as governing their relations with each other. To charge a nation with a violation of this law was, simply to charge it with a breach of its own agreement, with bad faith towards other nations. International law was nothing more or less than the rules of the game which had been adopted by the consent of all civilised Governments. ${ }^{1}$ If there were no rules for the government of states in their conduct towards each other except their own ideas of right and wrong, there would be no end to disputes in international relations. It was necessary for states to agree together as to their mutual

- Professor of Law, Victoria University College 1906-1907. This is a report from the New Zealand Mail Wellington, 1 August 1906.

1 On the basic role of consent (or agreement) see, for example, Salmond Jurisprudence (3 ed, Stevens \& Haynes, London, 1910) 55-56. 
rights and duties and to bind themselves by their own consent to a code of rules which may not be ideally just, but which certainly afforded a basis for the settlement of the quarrels of rival nations. It might confidently be expected that in the not distant future the law of nations would be embodied in treaties in the observance of which the nations would pledge themselves before the world.

\section{THE ADVANCE OF HUMANITY}

The principal compacts affecting international law were the Treaty of Paris, the Geneva Convention, the Declaration of St Petersburg, and, transcending all in importance, that document signed at The Hague in $1899,{ }^{2}$ which might justly be regarded as the opening of a new era in international relations. It contained 138 clauses, laying down new rules of international relations, partly for the settlement of disputes by arbitration and partly for the conduct of war. The history of modem times showed that international law was not a dead letter. It was a living force that did in fact govern and control the actions of states and secured to a very large extent the claims of justice, peace, humanity and honourable dealing; and no one possessing faith in the future of humanity need doubt that the law of nations was destined to grow in strength and increase in stature until it dominated the whole society of nations just as the law of the land dominated the individuals of the community. Open and admitted defiance of the law of nations might be stated to be unknown. When charges of breach of international law were made against a nation it generally turned out that there was an honest difference of opinion as to what the law really was. International law made no attempt to forbid war as unjust. It aimed first of all at diminishing the occasions and causes of war by defining the rights of nations. Secondly, it could, and did, to a large extent, purify warfare from those horrors of early times of which the sacking of Magdeburg and Badajos were terrible examples. ${ }^{3}$ Thirdly, it endeavoured to introduce arbitration.

\section{THE SECURITY OF THE CIVILIAN}

War was now exclusively a matter of armies and navies. The civil population was immune; it could go on with its usual avocations or watch the great tragedy as a spectacle. All shipping belonging to one of the belligerents, whether carrying private property or not,

2 Declaration of Paris respecting maritime law 1856; Geneva Convention 1864 for the amelioration of the condition of the wounded in armies in the field; Declaration of St Petersburg 1868; and the treaties adopted by the Hague Peace Conference 1899 on the pacific settlement of international disputes, the laws and customs of war and other matters. Ministry of Foreign Affairs and Trade, New Zealand Consolidated Treaty List: Part 1 Multilateral Treaties (1997) 32-33, 40-42.

3 Magdeburg is a city situated on the Elbe River, southwest of Berlin. In 1631, during the thirty years war, Johann von Tilly burned and sacked the city and butchered most of its 40,000 inhabitants. Badajos is a city in the southwest of Spain, close to the Portugese border. It is possible that Salmond was referring to an incident during the Peninsular War of 1811-12. 
was lawful prey. The difficult question arose when a neutral vessel was encountered. As the law now stood, England would probably suffer greater losses in a war than she could ever hope to inflict upon her enemies. But the civil population was not immune from the right of an invading army to exact requisitions, that is, to live at the expense of the invaded country. Civilians were also to some extent at the mercy of the right which the enemy professed to bombard a beseiged city. There was no rule to protect a city so long as a siege lasted from the utmost rigour of the operations. It was lawful for the besiegers to purposely pour shot and shell into the residential portion of it. It had been suggested that if England were at war with a maritime power hostile cruisers would escape, and, visiting our coasts, would attempt to exact huge sums of money as ransom from unprotected seaports under threat of bombardment and destruction. There was no doubt that schemes for such forms of warfare had existed in the minds of foreign naval authorities.

\section{IF WAR CAME TO NEW ZEALAND}

In 1878, when there was danger of war with Russia the Vladivostock fleet had received instructions that on the outbreak of war it was to sail for Australasian ports and exact ransom. ${ }^{4}$ A French admiral had recently publicly expressed the opinion that the true naval policy of France in the event of war with England was to use its fleet to attack the unprotected coast towns of England, and destroy them or hold them to ransom. International lawyers, however, were unanimously of opinion that such a mode of warfare would be utterly illegal and unjustifiable. Any attempt by a modern state to revive in this way the exploits of the Vikings and sea-robbers would arouse the execration of the civilised world, and would be visited with the sternest retribution. But if we had not to fear the destruction of our coastal towns and the exaction of ransom, what had we to fear? There were three things. Firstly, an enemy could exact the necessary supplies of coal, provisions, and the other requisities of a fleet and could enforce its demands under threat of bombardment. Secondly, a hostile squadron could land its crews to attempt to take possession of a port, though except as part of an organised scheme of invasion and conquest this would be entirely futile. The danger of any attempt at invasion and conquest was entirely imaginary. Foreign troops would find it a great deal easier to get into New Zealand than to get out of it again, and we might be fairly confident that we were not threatened with these risks. The third and real danger to which we were exposed was the capture and destruction of our ships and their cargoes. This was a real danger and was a sufficient

4 Professor Salmond may have been referring to tensions between Britain and Russia arising out of the Russo-Turkish war of 1877-78. The victorious Russians imposed the Treaty of San Stefano on the Turks, whereby a large independent Bulgarian state would be created. Britain vigorously opposed this treaty, fearing that the creation of the new state would lead to Russian dominance of the Balkans and the straits. As a result, Russia was forced at the Congress of Berlin in June 1878 to accept a much smaller Bulgaria. 
justification for the expenditure of much money in fortifying our harbours, maintaining ships of war, and contributing to the cost of the imperial ships in Australian waters. If a single hostile cruiser was free to prey upon Australasian commerce it would in a few weeks cause enormous losses that would paralyse our trade and strike a blow at our prosperity that would be felt for years to come.

\section{DAWN OF A NEW ERA}

Few people realised how often arbitration had been employed in international disputes. During the last hundred years there had been a good many more than a hundred cases, and with only one exception the awards of the international tribunals had been loyally fulfilled by the unsuccessful state. ${ }^{5}$ In the single instance referred to the state aggrieved justified itself on the ground that the arbitrators had exceeded their powers. It was an impressive thing to see nations with great armies and navies at command, voluntarily submitting their right and lawful claims to a tribunal and faithfully and honourably performing the judgments given against them. The fact that this had actually taken place in so many cases was full of hope and promise for the future.

5 During the hundred year period prior to the publication of Professor Salmond's inaugural address on 1 August 1906, arbitration was employed in approximately 275 disputes between states. Awards were made in the majority of these arbitrations and the awards appear in large part to have been accepted by the parties. Alexander Stuyt (ed) Survey of International Arbitrations 17941989 (3rd ed, Dorderecht, Boston, 1990) 9-288. The exception to which Professor Salmond was referring may have been the award made in a dispute between Great Britain and Venezuela on 3 October 1899 concerning the boundary line between the Colony of British Guiana and the United States of Venezuela. Venezuela later contended that the award was null and void. Gillis Wetter The International Arbitral Process: Public and Private vol III (Oceana Publications, Dobbs Ferry (NY), 1979) 4, 140. 